\title{
Kinetics, Isotherms and Thermodynamic Studies on Removal of Divalent Copper using Mallet Flower Leaf Powder as Bio-Adsorbent
}

\author{
Devarapalli Venkata Padma ${ }^{1,2}$ and Susarla Venkata Ananta Rama Sastry ${ }^{2, *}$ \\ ${ }^{I}$ Department of Chemical Engineering, A.U.C.O.E (A), Visakhapatnam, India \\ ${ }^{2}$ Department of Chemical Engineering, MVGR College of Engineering (A), Vizianagaram, India
}

('Corresponding author's e-mail: svarsastry@yahoo.com)

Received: 16 July 2020, Revised: 23 May 2021, Accepted: 16 June 2021

\begin{abstract}
The effectiveness and efficacy of Mallet Flower Leaf Powder (MFLP) as a bio-sorbent for the removal of heavy metal copper ions from the aqueous solutions have been studied. Experiments were conducted varying the $\mathrm{pH}$, agitation time, temperature, biosorbent size and dosage as parameters. Speed of the mixing is kept at $200 \mathrm{rpm}$. The analysis of copper was done by using Atomic Absorption Spectrophotometer (AAS). The adsorption of copper was found to be dependent on $\mathrm{pH}$ and a maximum removal of $98.78 \%$ was obtained at an optimum $\mathrm{pH}$ of 6.0. The optimum biosorbent dosage was $1 \mathrm{~g}$ for an agitation time of $40 \mathrm{~min}$. The biosorption data obtained were validated for the best isotherm. The data collected were verified with the available adsorption isotherms. Experimental data obtained was well represented by Langmuir $\left(\mathrm{R}_{\mathrm{L}}=0.161, \mathrm{qm}=5.96 \mathrm{mg} / \mathrm{g}, \mathrm{R}^{2}=0.9142\right)$, Freundlich $\left(\mathrm{n}=0.64, \mathrm{~K}_{\mathrm{f}}=0.79 \mathrm{~L} / \mathrm{g}\right.$, $\left.\mathrm{R}^{2}=0.9995\right)$ and Tempkin $\left(\mathrm{R}^{2}=0.9083, \mathrm{~b}_{\mathrm{T}}=267.63\right)$ isotherms, indicating favorable biosorption. The experimental data obtained were tested for the best fit and the Freundlich Model has yielded the best correlation with the highest regression coefficient, $\mathrm{R}^{2}=0.9844$. Kinetic data has also been presented using thermodynamic analysis and the pseudo second order model was found to be the best fit with a correlation coefficient of 0.999 . For the removal of copper from the solution, bioadsorbent showed a maximum adsorption capacity of $5.96 \mathrm{mg} / \mathrm{g}$.
\end{abstract}

Keywords: Biosorption, Copper, FTIR, Heavy metals, Mallet Flower Leaf Powder (MFLP)

\section{Introduction}

The industries are responsible for the contamination of water resources. Conventional methods like precipitation, reduction, reverse osmosis, ion exchange, evaporation, and electro dialysis are economically viable for a high concentration of copper in wastewater [1-3]. When the concentration is low then adsorption is the only method that is economically viable. Conventional adsorbents such as Zeolites, Activated carbon, Activated alumina, Silica gel, Activated clay, Fullers' earth, Bone char, Alginates, etc. have been used to remove copper from wastewater. However, due to the high cost of these adsorbents and loss of activity during storage, regeneration and recycling; many investigators tried several low-cost adsorbents made from agricultural waste [4-6].

The present study is intended to remove Copper (II) from wastewater using low-cost adsorbent like Mallet Flower Leaf Powder (MLFP). The parameters covered are agitation time ( $\mathrm{t}$ ) adsorption dosage $\left(\mathrm{l}_{\mathrm{a}}\right)$, $\mathrm{pH}$, adsorbent particle size, $\left(\mathrm{d}_{\mathrm{p}}\right)$ temperature $(\mathrm{T})$, and initial concentration of Copper. The effect of these parameters on percentage removal $\left(\mathrm{R}_{\mathrm{m}}\right)$ or recovery $\left(\mathrm{R}_{\mathrm{c}}\right)$ and on metal uptake $\left(\mathrm{q}_{\mathrm{e}}\right)$ is studied by conducting batch experiments.

Experiments were carried out to determine the adsorption capacity or the metal uptake ' $\mathrm{qe}_{\mathrm{e}}$ ' of the MFLP adsorbent. Parameters studied were initial metal ion concentration of the experimental stock solutions, $\mathrm{C}_{0}$; time of agitation; adsorbent particle size; temperature, and $\mathrm{pH}$. The effect of these parameters on the removal of metal ions of $\mathrm{Cu}(\mathrm{II})$ was studied. 


\section{Materials and methods}

\section{Preparation of the adsorbent}

The adsorbent was prepared using mallet flower leaf powder (Scientific name: schefflera pucckleri). The leaves are collected from the campus of MVGR College of Engineering (A), Vizianagaram, Andhra Pradesh, India. The leaves are washed with the tap water, sun dried, grinded using ultra-fine grinder and then screened through BSS meshes (100,150,240 mesh).

\section{Batch mode adsorption studies}

Batch experiments were carried out using $250 \mathrm{~mL}$ conical flasks. Stock solution was diluted with distilled water to make various concentrations of metal ions solutions varying from $20-100 \mathrm{ppm}$. The specific quantity of adsorbent $(0.2-1.0 \mathrm{~g})$ was added to the solution and agitated at $200 \mathrm{rpm}$ in a rotary shaker for a predetermined period $(5-90 \mathrm{~min})$. The adsorbate was then decanted and separated from adsorbent using (Whatman no. 40) filter paper [7-9]. The clear solution was collected in sample bottles and stored for analysis using Atomic Absorption Spectrophotometer (AAS), model Pinnacle-500.

The percentage removal of Copper is calculated from Eq. (1);

$($ Co - Ce $) \times 100 /$ Co

where $C_{o}$ and $C_{e}(\mathrm{mg} / \mathrm{L})$ are the initial concentration (before adsorption) and final concentration (after adsorption).

\section{Batch mode desorption studies}

Batch desorption studies were performed in order to find whether the copper adsorption on the studied adsorbent is reversible or not. It is seen that the copper adsorption process is irreversible [10-12].

\section{Results and discussions}

\section{Characterization of MFLP}

\section{Scanning electron microscopy (SEM) analysis}

SEM images of MFLP before Copper adsorption are shown in Figures 1(a) - 1(d). SEM showed the morphology and surface texture of MFLP at different magnifications. The adsorbent surface morphology revealed porous and zig-zag parts for the MFLP before adsorption and thus show the active sites [13-15].

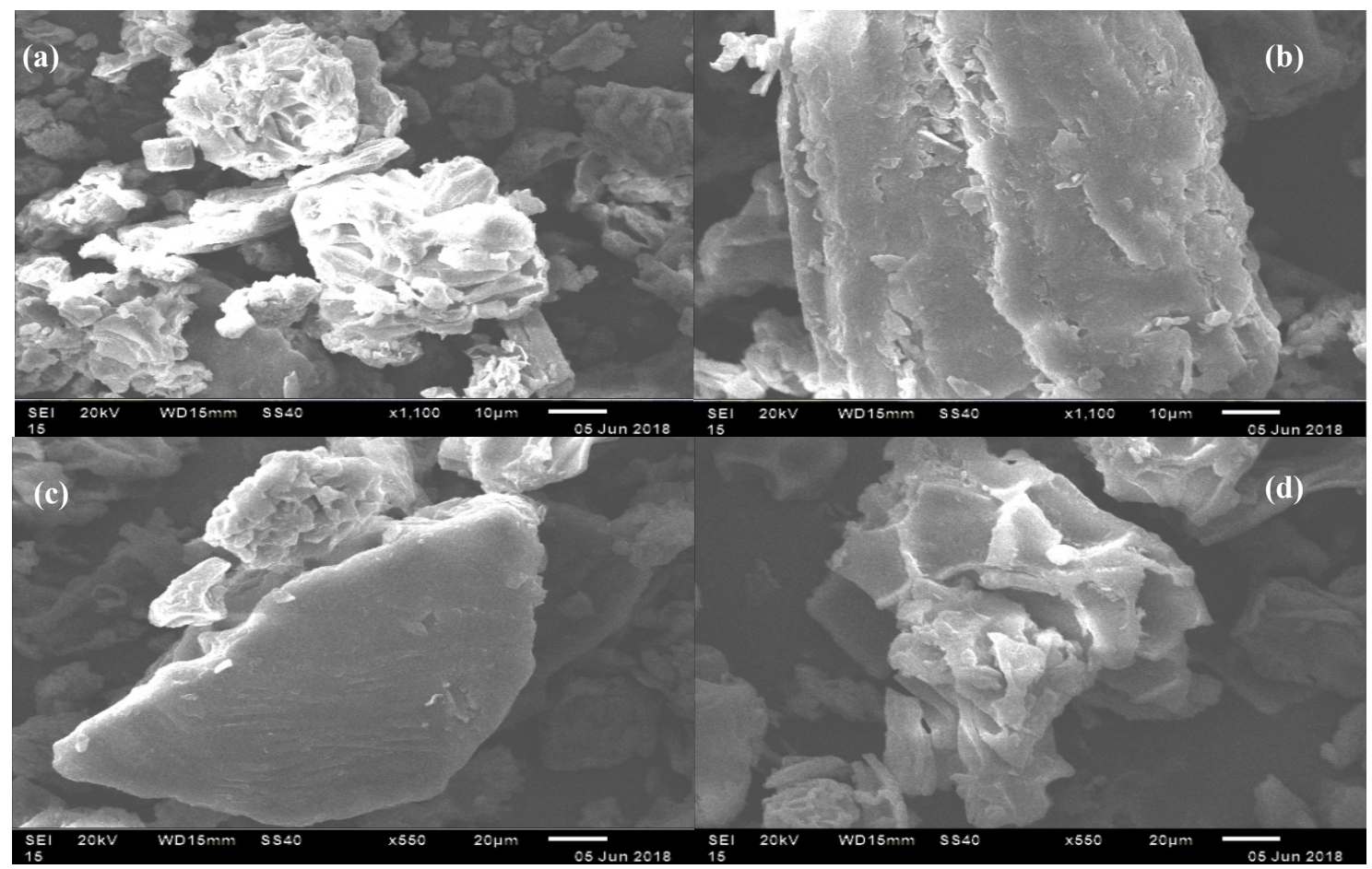

Figures 1(a) - 1(d) SEM micrographs of MFLP before adsorption of Copper. 
SEM images of MFLP after Copper adsorption are shown in Figure 1(e) - 1(h). The adsorbent surface morphology shows that the active sites were occupied by the metal ions after adsorption [22].

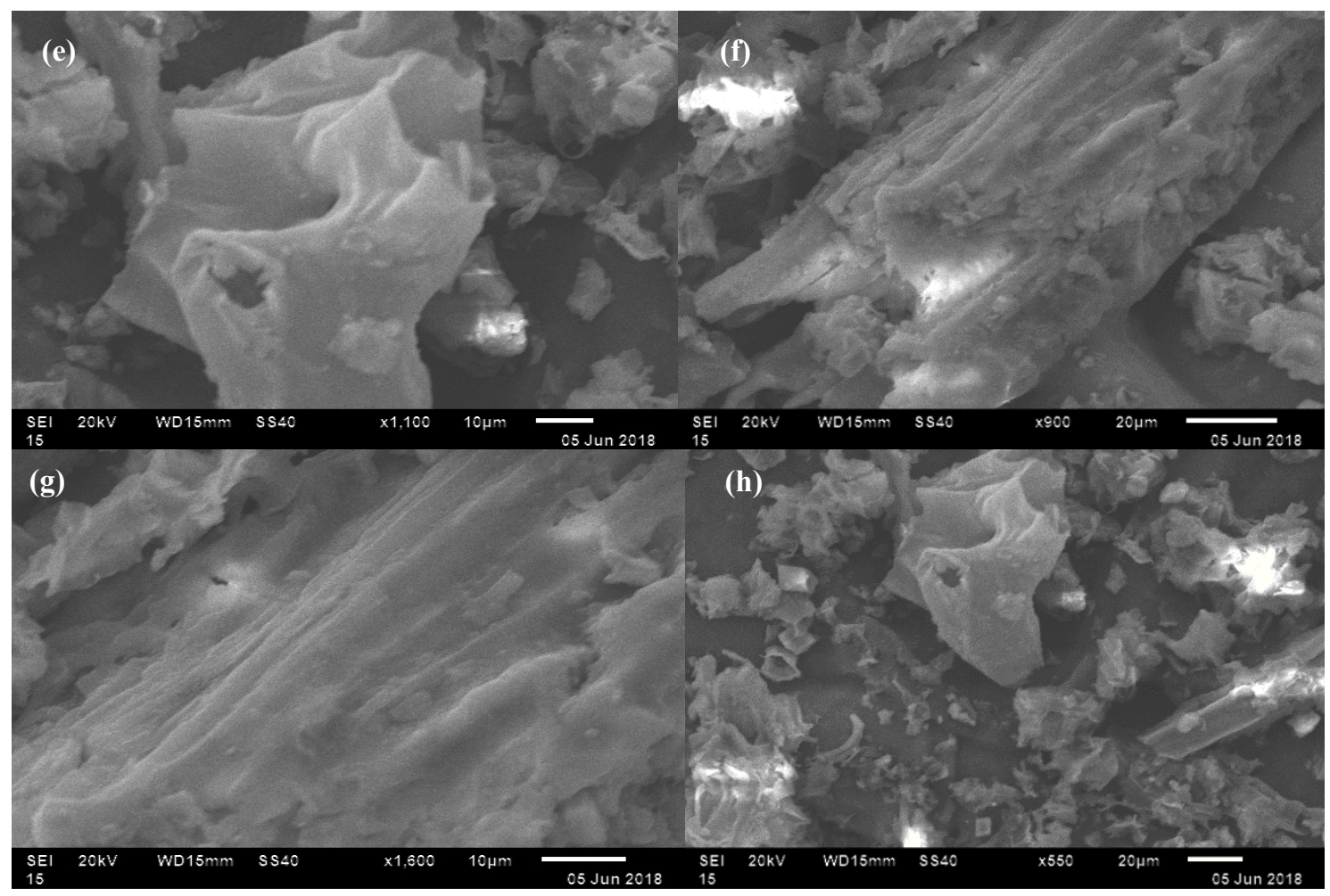

Figures 1(e) - 1(h) SEM micrographs of MFLP after adsorption of Copper.

\section{Fourier transform infrared (FTIR) analysis}

The adsorbent was characterized by using FTIR. FTIR has been shown for characterization and identification of functional groups, to understand the chemical composition of the adsorbent, which is very important for the uptake of metal ions. FTIR of adsorbent before and after Copper adsorption is shown in Figures 2(a) - 2(b).

The range of wave number for the FTIR spectrum is from 400 to $4000 \mathrm{~cm}^{-1}$. The peak, located at $2150 \mathrm{~cm}^{-1}$ is the characteristic peak of carbonyl group. According to Figure 2, a broad band at $3420 \mathrm{~cm}^{-1}$ is due to $-\mathrm{OH}$ group stretching. It can be concluded that hydroxyl and carbonyl were the main components of the adsorbent. It also shows that after adsorbing $\mathrm{Cu}(\mathrm{II})$, the peaks at 2150 and $3420 \mathrm{~cm}^{-1}$ reduced. This indicated the surface functional groups of adsorbent could combine with $\mathrm{Cu}(\mathrm{II})$ intensively. These groups had been reported to enhance metal ions adsorption [16-18]. 


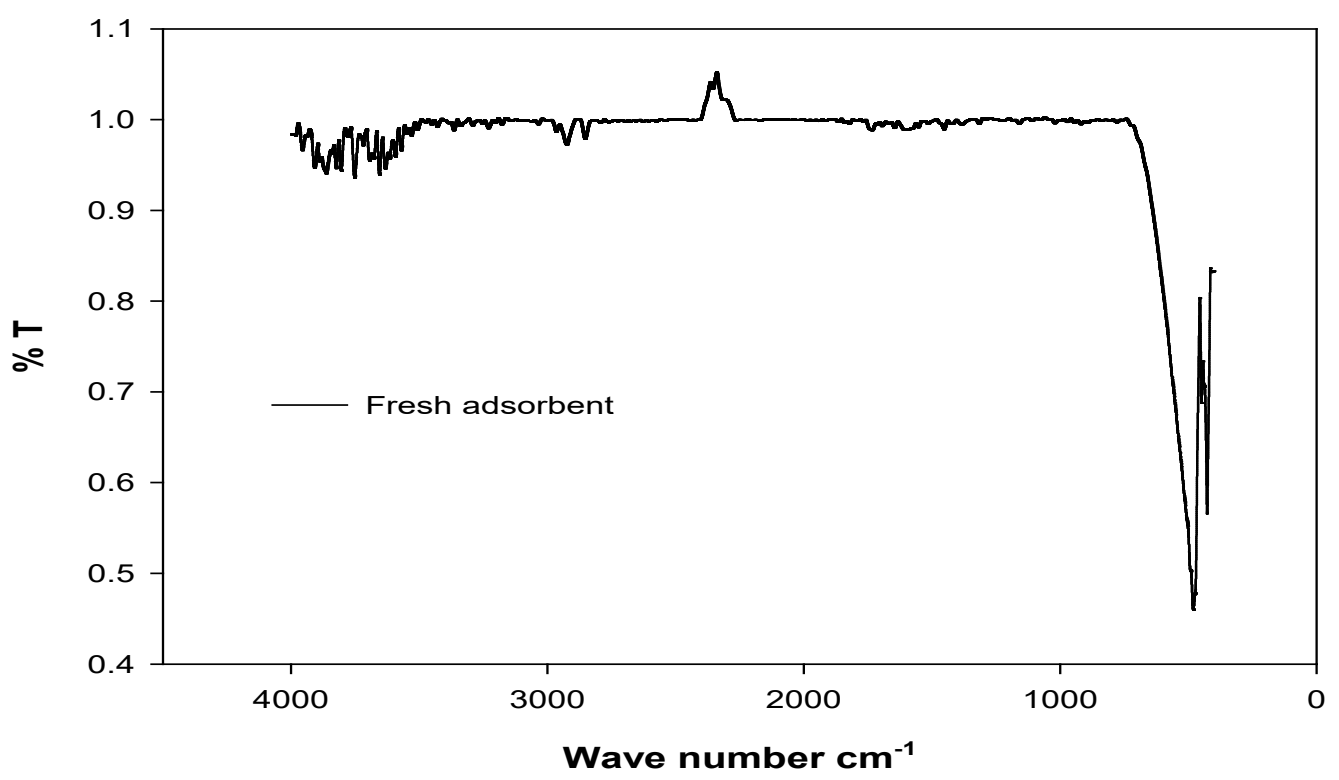

(a)

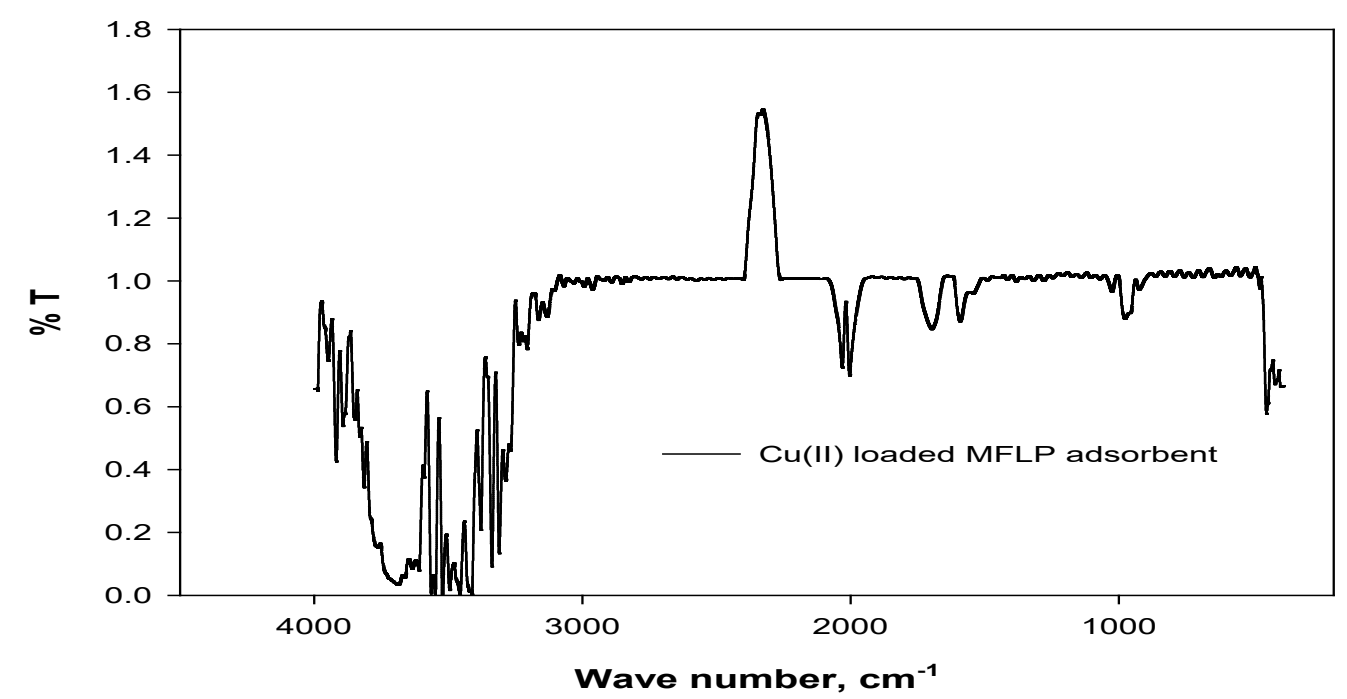

(b)

Figure 2 (a) FTIR image of pure adsorben and (b) FTIR image of $\mathrm{Cu}$ loaded adsorbent.

Effect of operating parameters on adsorption process

Different parameters are studied to evaluate the effect of adsorbent dosage, initial metal ion concentration, $\mathrm{pH}$, contact time and temperature on removal of Copper using MFLP adsorbent (Table 1). 
Table 1 Parameters studied for batch experimentation.

\begin{tabular}{|c|c|c|c|c|c|c|}
\hline Parametric study & $\begin{array}{c}\text { Metal ion } \\
\text { concentration } \\
(\text { ppm) }\end{array}$ & $\begin{array}{c}\begin{array}{c}\text { Adsorbent } \\
\text { dosage } \\
\text { (g) }\end{array} \\
\end{array}$ & $\begin{array}{c}\text { Agitation } \\
\text { time } \\
(\mathrm{min})\end{array}$ & pH & $\begin{array}{c}\text { Temperature } \\
\left({ }^{\circ} \mathrm{C}\right)\end{array}$ & $\begin{array}{c}\text { Adsorbent } \\
\text { Size } \\
\text { (microns) }\end{array}$ \\
\hline $\begin{array}{c}\text { Metal ion } \\
\text { concentration }\end{array}$ & $20-100$ & 1 & 40 & 6 & 30 & 106 \\
\hline Adsorbent dosage & 20 & $0.2-1$ & 40 & 6 & 30 & 106 \\
\hline Agitation time & 20 & 1 & $5-90$ & 6 & 30 & 106 \\
\hline $\mathrm{pH}$ & 20 & 1 & 40 & $2-10$ & 30 & 106 \\
\hline Temperature & 20 & 1 & 40 & 6 & $10-50$ & 106 \\
\hline Adsorbent size & 20 & 1 & 40 & 6 & 30 & $74-149$ \\
\hline
\end{tabular}

\section{Effect of agitation time on adsorption}

The data on percentage removal of copper were plotted against time is shown in Figure 3 for different MFLP dosage values. The percent removal found to be very rapid in the initial $5 \mathrm{~min}$ and subsequently it is progressively raised to $40 \mathrm{~min}$ of agitation time. The percentage removal is nearly stable after $40 \mathrm{~min}$. So, the equilibrium adsorption time for copper is observed to be $40 \mathrm{~min}$ [19-21].

The percentage removal has increased from 91.95 to $96.38 \%$ in the time interval of $5-40 \mathrm{~min}$. The percentage removal is higher initially, because of higher available surface area of the adsorbent and hence more surface adsorption sites, leading to better biosorption of copper. As the time proceeds, gradually the vacant active sites on adsorbent surface are fully occupied leaving no site for further adsorption. This results in equilibrium adsorption reaction between adsorbate, $\mathrm{Cu}$ (II) in solution and $\mathrm{Cu}$ (II) on adsorbent surface [22-24].

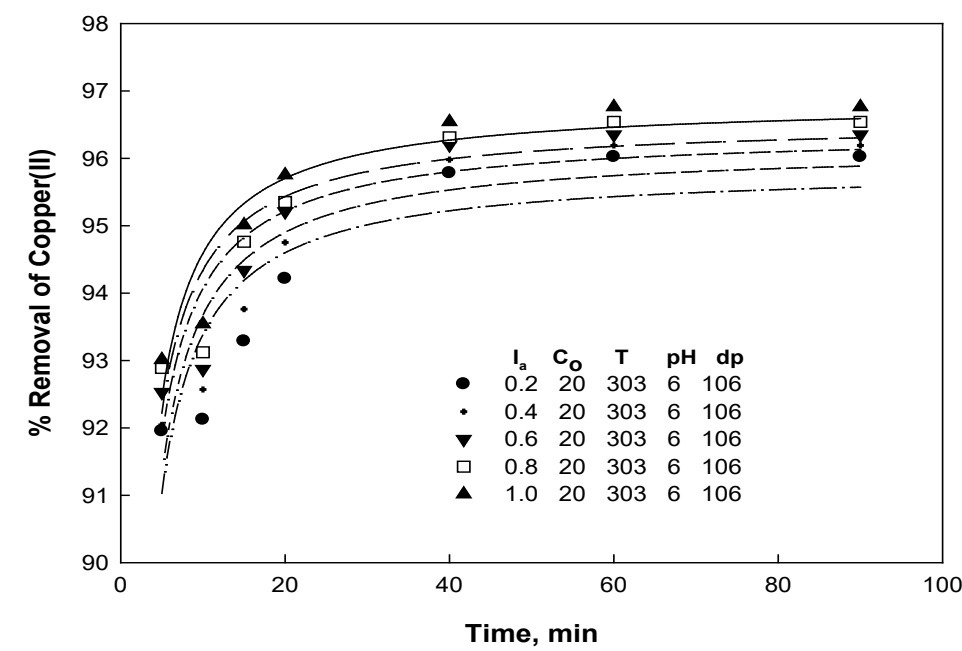

Figure 3 Effect of agitation time on adsorption of $\mathrm{Cu}$ (II).

[I $I_{a}$-adsorbent dosage, $C_{o}$-Concentration, T-Temperature, dp-Adsorbent size]

\section{Effect of initial concentration in aqueous solution}

The effect of initial concentration of $\mathrm{Cu}$ (II) on the percentage removal of $\mathrm{Cu}$ (II) is shown through a graph in Figure 4. The percentage removal is slightly reduced from 98.78 to 98.5 by raising initial $\mathrm{Cu}$ (II) concentration $\left(\mathrm{C}_{\mathrm{o}}\right)$ from 20 to $100 \mathrm{ppm}$ [25-27]. At lower initial concentrations of $\mathrm{Cu}(\mathrm{II})$, adsorption was found to be a maximum of $98.78 \%$. For greater $\mathrm{Cu}$ (II) concentration, lesser percentage of $\mathrm{Cu}$ (II) was removed. Such performance is ascribed to the rise in the quantity of adsorbate to the fixed number of accessible active sites on adsorbent (as the quantity of adsorbent is kept constant) [22]. 


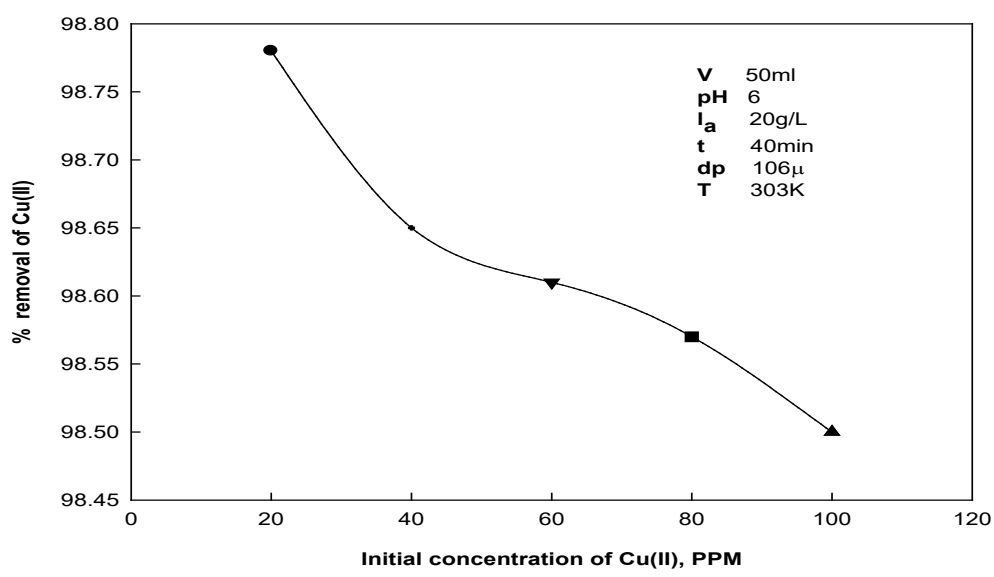

Figure 4 Effect of initial concentration in ppm on \% recovery of Copper.

\section{Effect of MFLP size on adsorption}

The percentage removal of $\mathrm{Cu}(\mathrm{II})$ has progressively risen with decreasing size of adsorbent particles, as seen from the plots of Figure 5. The percentage removal increased from 85.49 to 97.1 as the adsorbent particle size decreased from 149 to $74 \mu$. This trend is expected as size of MFLP reduces, the surface area of MFLP obviously increases, and thereby a greater number of active sites on the adsorbent are better exposed to adsorbate [28-30].

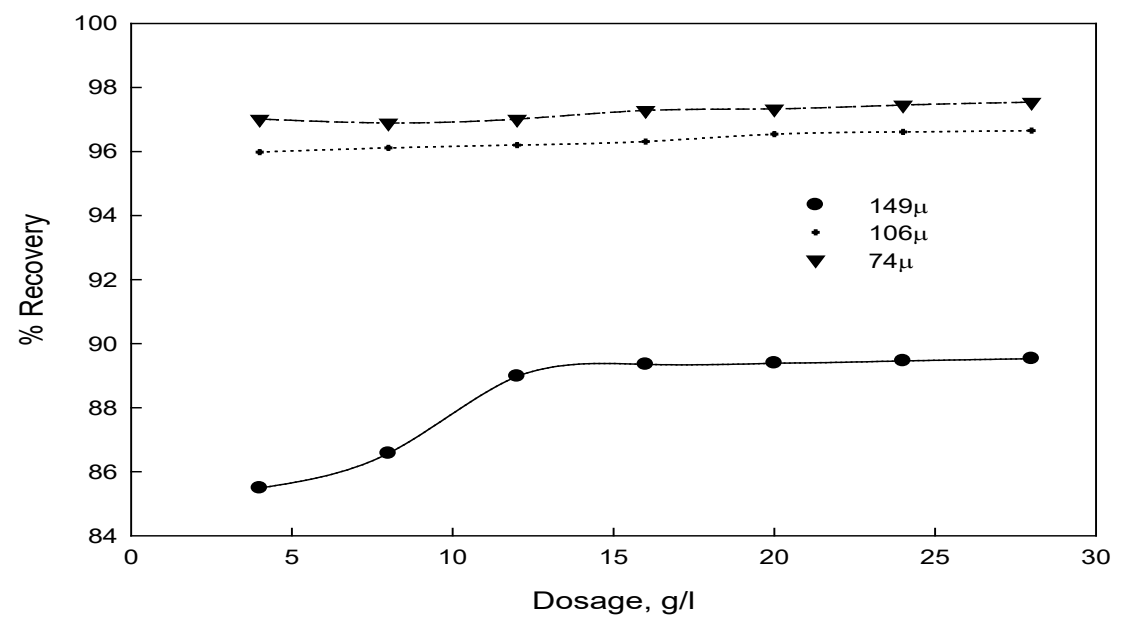

Figure 5 Effect of MFLP particle size on \% removal of $\mathrm{Cu}(\mathrm{II})$.

Figure 5 signifies the difference in percentage removal of $\mathrm{Cu}(\mathrm{II})(\mathrm{pH}=6.0)$ against dosage of the adsorbent. The percentage removal was found to increase from 85.49 to 89.39 for particle size of $149 \mu$, while, for lower particle sizes there is no much variation in percentage removal when dosage is increased. As there is marginal $(\leq 1 \%)$ increase in the percentage removal when the particle size is decreased from 106 to $74 \mu$. Therefore, subsequent studies are carried out with $106 \mu$ particle size as optimum particle size of adsorbent for $\mathrm{Cu}(\mathrm{II})$ removal.

\section{Effect of solution $\mathrm{pH}$ on adsorption}

To find the effect of $\mathrm{pH}$ on percentage removal of Copper, plots are shown in Figure 6 for $\mathrm{C}_{\mathrm{o}}$ values of all aqueous solutions at $303 \mathrm{~K}, 106 \mu$ and $1 \mathrm{~g}$ adsorbent dosage. Considerable increase in percentage removal of $\mathrm{Cu}(\mathrm{II})$ is noticed as $\mathrm{pH}$ value is raised from 2 to 8 . A maximum of percentage 
removal of 98.78 was observed at a $\mathrm{pH} 6$. Beyond $\mathrm{pH} 6$, the values of percentage removal declined sharply for all initial sorbate solutions $\mathrm{C}_{\mathrm{o}}$. It was reported at lower $\mathrm{pH}$ values, the copper is present in different ionic forms in solution [31]. The active sites of adsorption surface of adsorbent tend to become positively charged and the negative radicals of Copper of the form $\left[\mathrm{Cu}(\mathrm{OH})_{3}\right]^{-}$have greater tendency to diffuse and adsorb on the positive adsorbent surface. While at higher $\mathrm{pH}$ values (above 6), conversion of copper to copper hydroxide is expected to be prevalent. The precipitated Copper loses its ability to adsorb on the adsorbent particle [32,33].

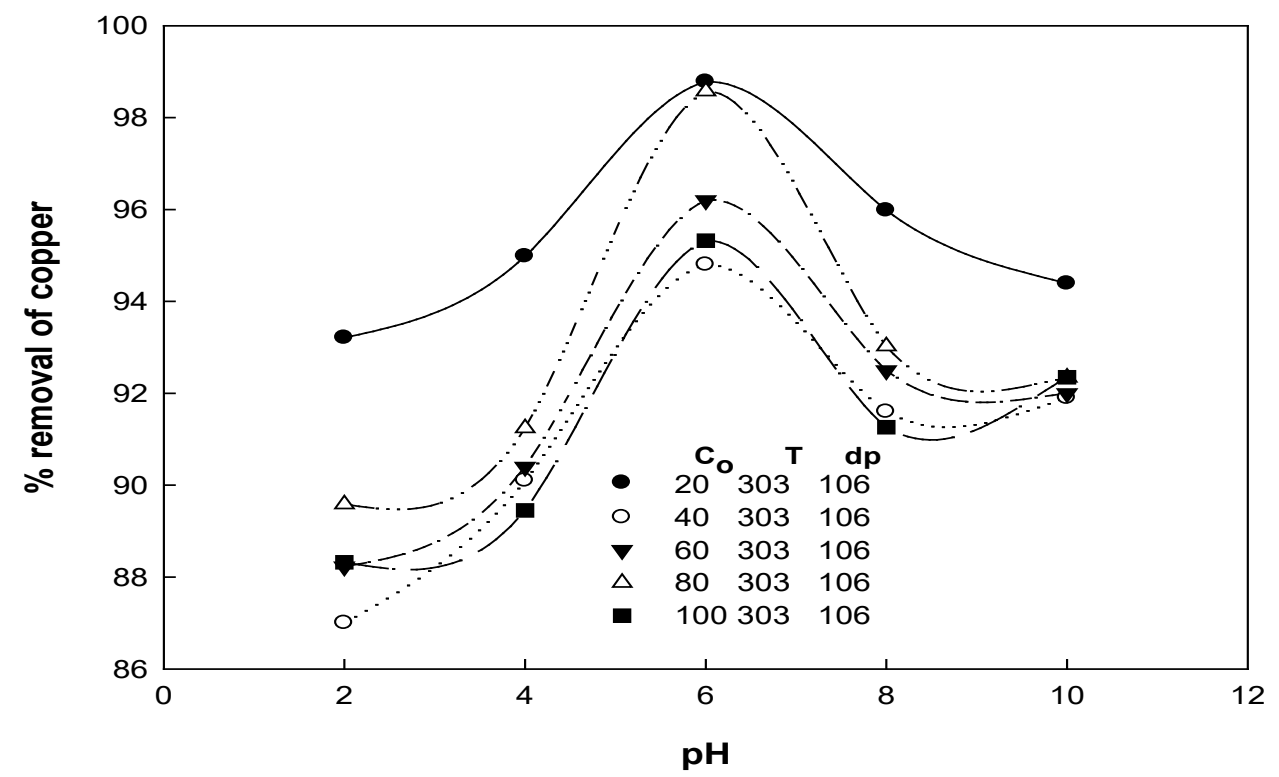

Figure 6 Effect of $\mathrm{pH}$ on adsorption of $\mathrm{Cu}(\mathrm{II})$.

\section{Desorption studies}

MFLP has good adsorption capacity. For this reason, it is necessary to find out the desorption characteristics of $\mathrm{Cu}(\mathrm{II})$ ions from MFLP. Experiments are conducted to investigate the desorption studies by proper treatment of the adsorbent without disturbing or damaging the structure either surface or internal structure of adsorbent. This would facilitate the re-use of adsorbent. The regeneration of the adsorbent renders any commercial adsorption process viable as fresh adsorbent need not be used [34-36].

The adsorbent after adsorption, is treated with suitable desorbents, normally acids or bases. In some cases, water also can be used as a successful desorbent.

The percentage of $\mathrm{Cu}$ (II) desorbed was determined by the Eq. (2);

$\%$ Desorption $=100 \times \frac{V_{D} C_{D}}{q_{e} m}$

where, $\mathrm{C}_{\mathrm{D}}=$ concentration of and $\mathrm{Cu}(\mathrm{II})$ desorbed,

$\mathrm{V}_{\mathrm{D}}=$ volume of desorbed solution,

$\mathrm{m}=$ mass of the adsorbed used for the study,

$\mathrm{q}_{\mathrm{e}}=$ Ads capacity of the adsorbent (metal uptake).

The $\%$ desorption of $\mathrm{Cr}$ (II) indicates the suitability of MFLP as a good adsorbent.

\section{Mechanism involved in desorption}

Desorption is reverse of the adsorption, but the path of the desorption determines the percentage of removal. Metal loaded adsorbent, after reaching equilibrium, is treated with a given normality (known concentration) of $\mathrm{NaOH} / \mathrm{HCl}$ for desorbing the metal ion. This is similar to solid-liquid leaching or extraction process.

As and when the metal loaded adsorbent is added to $\mathrm{NaOH}$ the concentration gradient between the sorbate on the adsorbent and sorbate in the desorbent initiates the desorption process. The basic nature of 
the desorbent solution facilitates the detachment of sorbate metal ions. As the concentration of $\mathrm{NaOH}$ is increased by 2.5 -fold, the percentage desorption increased significantly by about $40-45 \%$.

From the earlier adsorption studies, the data were found to fit well to Freundlich isotherm equation rather than Langmuir. This is suggestive that the adsorption of the sorbate on multilayer heterogenous surface is mostly favoured. In contrast, as $\mathrm{Cu}$ (II) absorption data showed a better fit to Langmuir isotherm equation, it is presumed that $\mathrm{Cu}(\mathrm{II})$ adsorption could have been caused on monolayer. $0.25 \mathrm{~N}$ desorbent $(\mathrm{NaOH})$ showed a maximum percentage desorption of $\mathrm{Cu}$ was $55 \%$. The other parametric data were fixed at: $\mathrm{pH}$ 2, Temp $303 \mathrm{~K}$, adsorbent dosage $1 \mathrm{~g}$, time of duration $40 \mathrm{~min}$ and the solution contains 20 ppm Cu.

Experimental conditions for this case were: $\mathrm{pH} 6$, temperature $303 \mathrm{~K}$, adsorbent dosage $1 \mathrm{~g}$, time duration $40 \mathrm{~min}$ and the solution contains $20 \mathrm{ppm} \mathrm{Cu}$. The percentage desorption of $\mathrm{Cu}$ was $52 \%$ at $\mathrm{HCl}$ concentration of $0.25 \mathrm{~N}$.

\section{Adsorption isotherms}

\section{Langmuir adsorption isotherm}

The adsorption data on $\left(\mathrm{C}_{\mathrm{e}} / \mathrm{q}_{\mathrm{e}}\right)$ was plotted against $\mathrm{C}_{\mathrm{e}}$ for $\mathrm{Cu}(\mathrm{II})$ and shown in Figure 7 . The data on $\mathrm{Cu}(\mathrm{II})$ were found to fit well with Langmuir Isotherm equation and Eq. (3) was obtained from regression of the data (Table 2).

$\frac{c_{e}}{q_{e}}=0.103 C_{e}+0.985$

$\mathrm{q}_{\mathrm{m}}=9.62 \frac{\mathrm{mg}}{\mathrm{g}}$ and $\mathrm{R}_{\mathrm{L}}=0.3216, \mathrm{R}^{2}=0.818$

The separation factor $\mathrm{R}$, less than one indicates favorable biosorption, fulfilling Langmuir isotherm condition of $0<\mathrm{R}_{\mathrm{L}}<1$. The linear regression plots at all temperatures are shown in Figure 8 .

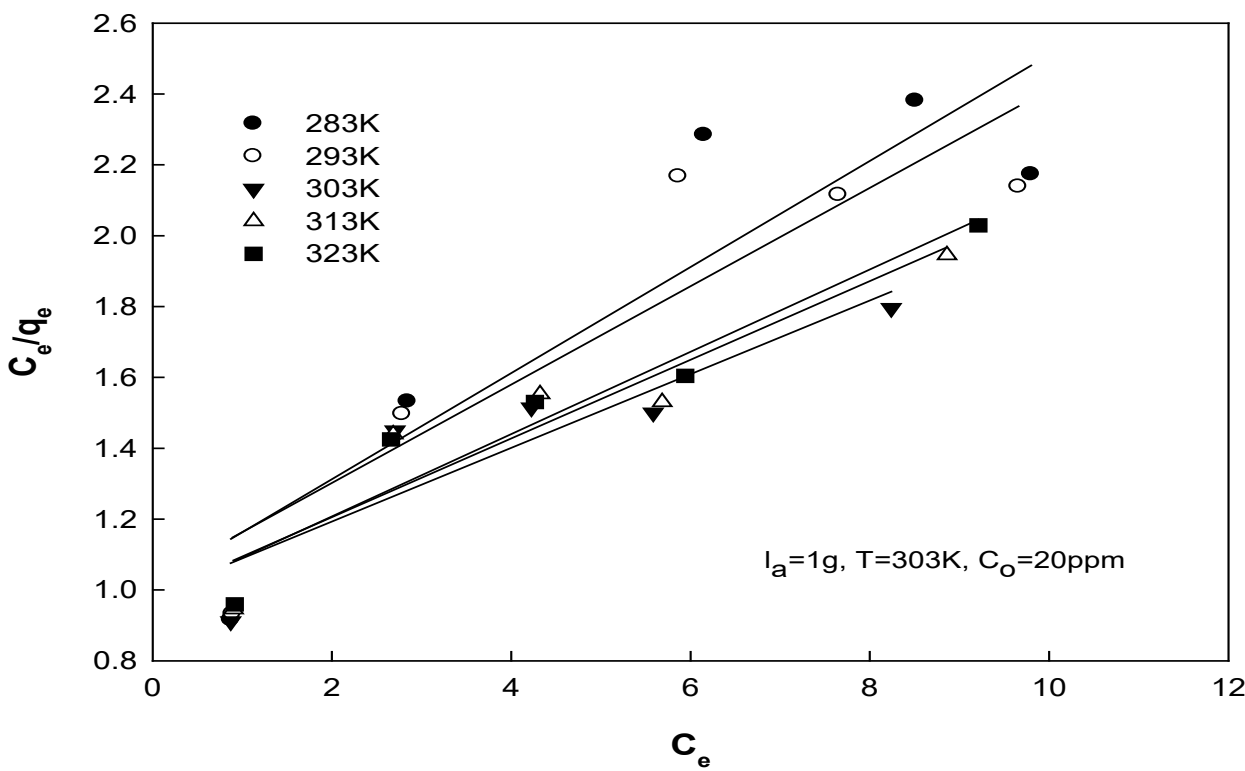

Figure 7 Langmuir isotherm for $\mathrm{Cu}(\mathrm{II})$. 
Table 2 Langmuir isotherm and its coefficients for $\mathrm{Cu}(\mathrm{II})$.

\begin{tabular}{ccccccc}
\hline S. No & $\begin{array}{c}\text { Temperature } \\
(\mathbf{K})\end{array}$ & Isotherm Equations & $\mathbf{q}_{\mathbf{m a x}}(\mathbf{m g} / \mathbf{g})$ & $\mathbf{b}$ & $\mathbf{R}_{\mathbf{L}}$ & $\mathbf{R}^{2}$ \\
\hline 1 & 283 & $\frac{C_{e}}{q_{e}}=0.1497 C_{e}+1.013$ & 6.680027 & 0.147779 & 0.252808 & 0.814 \\
2 & 293 & $\frac{C_{e}}{q_{e}}=0.1387 C_{e}+1.024$ & 7.209805 & 0.135449 & 0.269616 & 0.820 \\
3 & 303 & $\frac{C_{e}}{q_{e}}=0.1039 C_{e}+0.985$ & 9.624639 & 0.105482 & 0.32158 & 0.818 \\
4 & 313 & $\frac{C_{e}}{q_{e}}=0.111 C_{e}+0.983$ & 9.009009 & 0.11292 & 0.3069 & 0.883 \\
5 & 323 & $\frac{C_{e}}{q_{e}}=0.1161 C_{e}+0.975$ & 8.613264 & 0.119077 & 0.295723 & 0.975 \\
\hline
\end{tabular}

\section{Freundlich isotherm}

Similar analysis was made for the data on $\mathrm{Cu}$ (II) from the plotted data (Figure 8) in accordance with Freundlich isotherm equation. The results obtained are shown in Table 3.

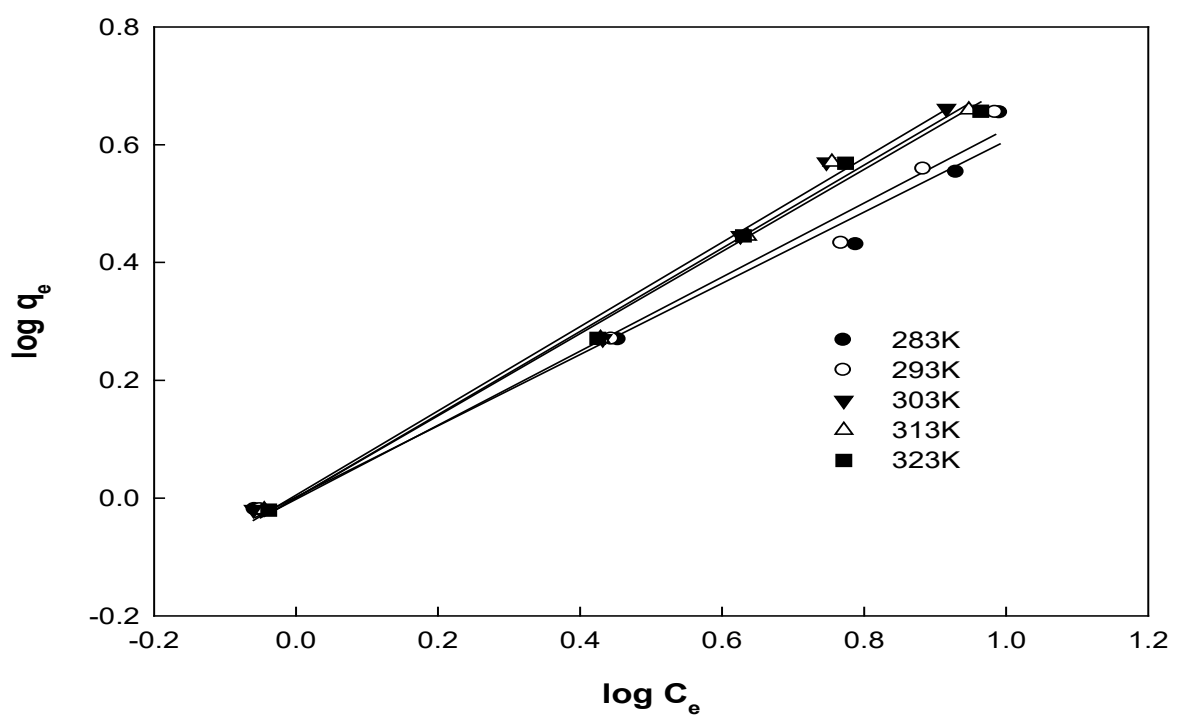

Figure 8 Adsorption data on $\mathrm{Cu}(\mathrm{II})$ in accordance with Freundlich Isotherm.

Table 3 Freundlich isotherm constants and coefficients for $\mathrm{Cu}(\mathrm{II})$.

\begin{tabular}{cccccc}
\hline S. No & $\begin{array}{c}\text { Temperature } \\
(\mathbf{K})\end{array}$ & Isotherm Equation & $\mathbf{K}_{\mathbf{f}}$ & $\mathbf{n}$ & $\mathbf{R}^{2}$ \\
\hline 1 & 283 & $\log q_{e}=0.604 \log C_{e}+0.0017$ & 1.004045 & 1.653986 & 0.98 \\
2 & 293 & $\log q_{e}=0.628 \log C_{e}-0.002$ & 0.995356 & 1.590837 & 0.985 \\
3 & 303 & $\log q_{e}=0.715 \log C_{e}+0.005$ & 1.011603 & 1.398601 & 0.988 \\
4 & 313 & $\log q_{e}=0.706 \log C_{e}+0.0003$ & 1.000807 & 1.416431 & 0.9908 \\
5 & 323 & $\log q_{e}=0.697 \log C_{e}+0.0001$ & 1.000414 & 1.43472 & 0.9938 \\
\hline
\end{tabular}




\section{Tempkin isotherm}

Similar analysis of the data on the adsorption of $\mathrm{Cu}$ (II) yielded the following isotherms at different temperatures (Figure 9, Table 4).

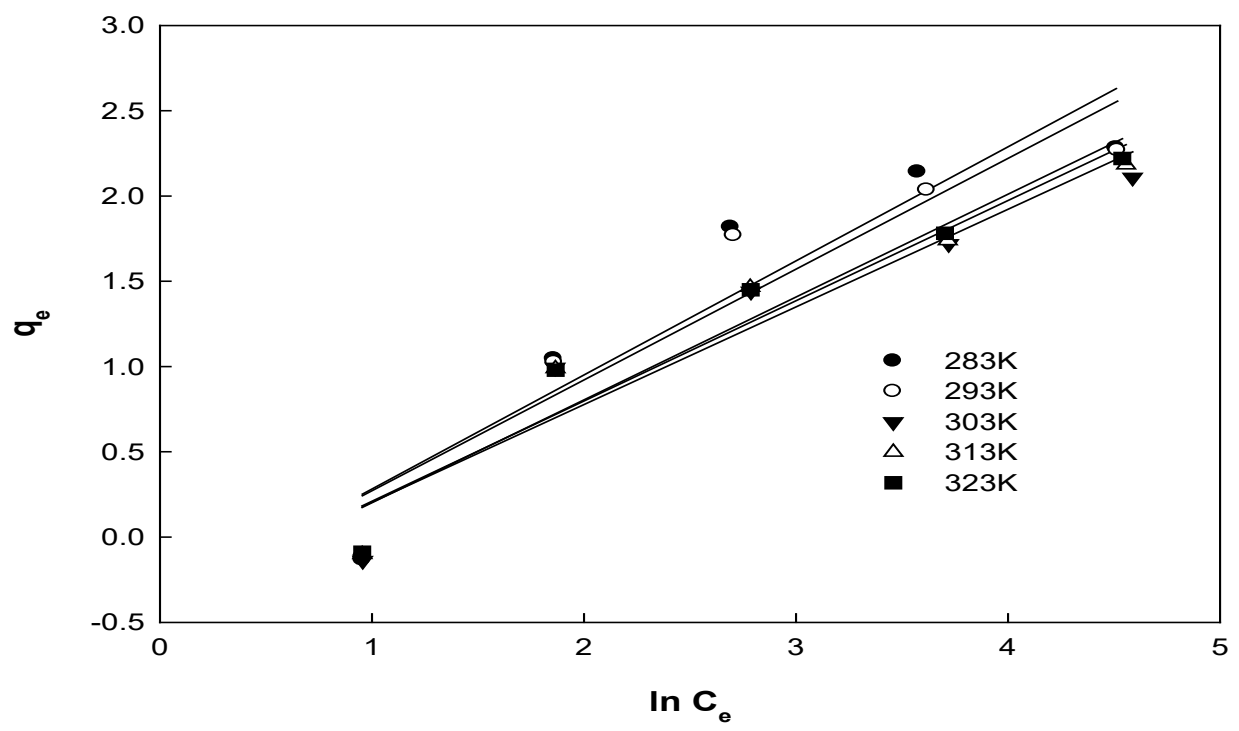

Figure 9 Temkin isotherm for $\mathrm{Cu}(\mathrm{II})$.

Table 4 Temkin isotherm constant and the regression data for copper.

\begin{tabular}{cccccc}
\hline S. No & Temperature (K) & Isotherm Equation & $\mathbf{b}_{\mathbf{T}}$ & $\mathbf{A}_{\mathbf{T}}(\mathbf{L} / \mathbf{m g})$ & $\mathbf{R}^{\mathbf{2}}$ \\
\hline 1 & 283 & $\log q_{e}=0.669 \log C_{e}-0.388$ & 3516.984 & 0.559915 & 0.877 \\
2 & 293 & $\log q_{e}=0.649 \log C_{e}-0.378$ & 3751.158 & 0.558823 & 0.891 \\
3 & 303 & $\log q_{e}=0.572 \log C_{e}-0.368$ & 4401.017 & 0.52567 & 0.913 \\
4 & 313 & $\log q_{e}=0.588 \log C_{e}-0.379$ & 4425.65 & 0.525073 & 0.929 \\
5 & 323 & $\log q_{e}=0.603 \log C_{e}-0.401$ & 4454.914 & 0.514156 & 0.9429 \\
\hline
\end{tabular}

\section{Adsorption kinetics}

\section{Pseudo first order model}

The reaction rates of adsorbate-adsorbent system would provide good information for the design of a practical operating system to get better yield of removal/recovery of heavy metal ions either toxic or non-toxic from the effluent streams, within a given time constraint. Processing times can be optimized for quick and efficient removal or recovery processes. This information could be derived from the knowledge of the kinetics of reactions occurring between the adsorbent and adsorbate.

In view of the above, kinetic studies of adsorbent-adsorbate system of reactions have been carried out to arrive at a suitable mechanism of the reactions. Rates depicting the yields could be predicted from the different kinetic models provided, based on order of adsorbent-adsorbate reactions. Equilibrium data give the necessary drive for the transportation or diffusion of the solute (adsorbate) ions from solution to solid adsorbent surface. The kinetic studies could be modeled using the prevailing order within the given system.

Attempts are made to arrive at a suitable kinetic model for adsorption reactions between $\mathrm{Cu}$, adsorbate and MFLP adsorbent. The diffusion rates of ions from solution to surface of adsorbent are probably monitored or controlled by a boundary. The rate kinetics in most of such instances follow pseudo first order rate equation of Lagergren given in Eq. (4); 
$\frac{d q_{t}}{d t}=k_{a d}\left(q_{e}-q_{t}\right)$

where $\mathrm{q}_{\mathrm{e}}$ and $\mathrm{q}_{\mathrm{t}}$ are amount adsorbed at $\mathrm{t}(\mathrm{min})$ and equilibrium,

$\mathrm{K}_{\mathrm{ad}}$ is rate constant of pseudo first order adsorption process.

The above equation can be written as Eq. (5);

$\log \left(\mathrm{q}_{\mathrm{e}}-\mathrm{q}_{\mathrm{t}}\right)=\log \mathrm{q}_{\mathrm{e}}-\left(\frac{\mathrm{k}_{1}}{2.303}\right) \mathrm{t}$

Plot of ' $\log \left(\mathrm{q}_{\mathrm{e}}-\mathrm{q}_{\mathrm{t}}\right)$ ' vs. ' $\mathrm{t}$ ' gives straight line for the first order kinetics, making possible the calculation of first order rate constant $\left(\mathrm{K}_{\mathrm{ad}}\right)$ for the adsorption process.

The above equation may not represent the experimental data due to the following 2 reasons;

1) $\mathrm{K}_{\mathrm{ad}}\left(\mathrm{q}_{\mathrm{e}}-\mathrm{q}_{\mathrm{t}}\right)$ doesn't signify no. of accessible adsorption sites.

2) $\log \mathrm{q}_{\mathrm{e}}$ is not equivalent to intercept.

\section{Pseudo second order model}

If pseudo first order fails to fit in data, one can resort to the development of pseudo second order kinetic equation given as Eq. (6);

$\frac{d q_{t}}{d t}=K_{a d}\left(q_{e}-q_{t}\right)^{2}$

where ' $\mathrm{K}$ ' is the second order rate constant.

The above equation can be presented as Eq. (7);

$\frac{\mathrm{t}}{\mathrm{q}_{\mathrm{t}}}=\frac{1}{\mathrm{~K}_{\mathrm{ad}} \mathrm{q}_{\mathrm{e}}^{2}}+\frac{1}{\mathrm{q}_{\mathrm{e}}} \mathrm{t}$

For the pseudo second order kinetics, the plot of (t/qt) versus $t$ shown in Figure 10 gives a linear equation, Eq. (8), facilitating the computation of qe and $\mathrm{K}[6]$.

$\frac{t}{q}=0.189 t+0.132$

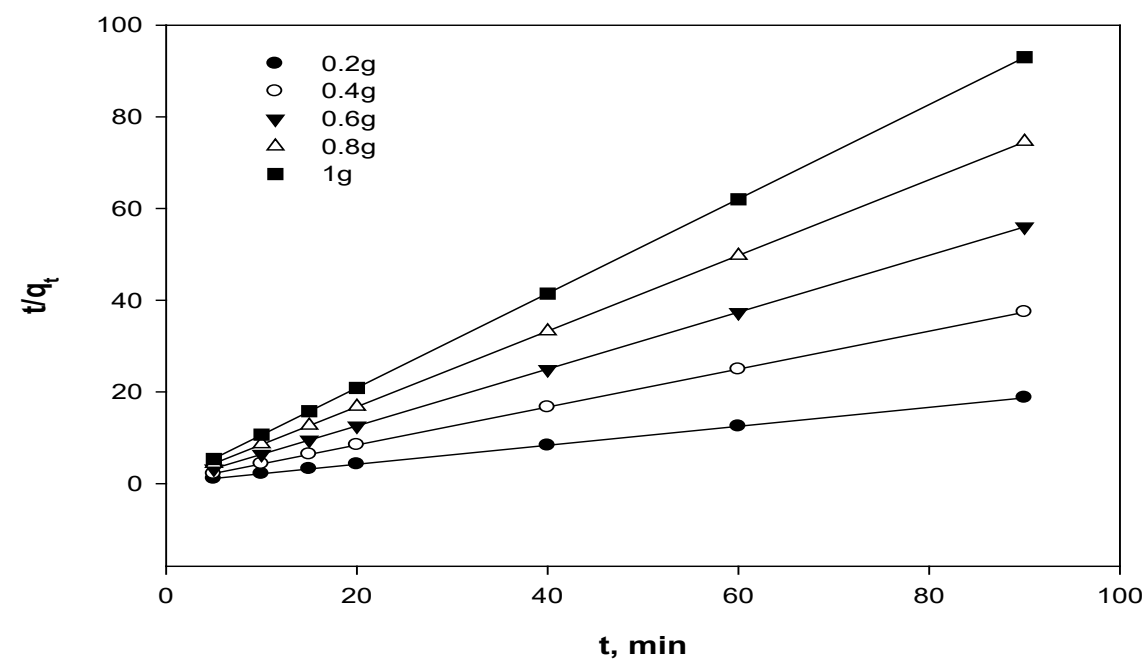

Figure 10 Psuedo second order kinetic model for $\mathrm{Cu}(\mathrm{II})$.

The data on $\mathrm{t} / \mathrm{q}$ (metal uptake and time (agitation time) for $\mathrm{Cu}$ (II) with a particle size of 106 microns, $20 \mathrm{ppm}$ solution, at a temperature of $303 \mathrm{~K}$ and $\mathrm{pH}=6.0$ are plotted for different adsorption dosages and shown in Figure 10. The calculated data $\mathrm{qe}_{\text {cal, }} \mathrm{qe}_{\mathrm{exp}}, \mathrm{R}^{2}$, Rate constant are shown in Table 5. 
Table 5 Pseudo second order model constants and coefficients.

\begin{tabular}{ccccccc}
\hline Kinetics & $\begin{array}{c}\text { Parameters } \\
\mathbf{p H}=\mathbf{2} \text { temperature }\end{array}$ & Model equation & $\mathbf{q e}_{\text {cal }}$ & $\mathbf{q e}_{\text {exp }}$ & $\mathbf{R}^{\mathbf{2}}$ & $\begin{array}{c}\text { Rate } \\
\text { constant }\end{array}$ \\
\hline & $\begin{array}{c}0.2 \mathrm{~g} / 50 \mathrm{~mL} \\
20 \mathrm{ppm}\end{array}$ & $\frac{t}{q}=0.207 t+0.083$ & 4.830 & 4.7890 & 0.999 & 0.00355 \\
\cline { 2 - 6 } & $\begin{array}{c}0.4 \mathrm{~g} / 50 \mathrm{~mL} \\
20 \mathrm{ppm}\end{array}$ & $\frac{t}{q}=0.413 t+0.150$ & 2.420 & 2.3995 & 0.999 & 0.02558 \\
\cline { 2 - 6 } $2^{\text {nd }}$ order & $\begin{array}{c}0.6 \mathrm{~g} / 50 \mathrm{~mL} \\
20 \mathrm{ppm}\end{array}$ & $\frac{t}{q}=0.620 t+0.196$ & 1.612 & 1.6033 & 0.999 & 0.07534 \\
\cline { 2 - 7 } & $\begin{array}{c}0.8 \mathrm{~g} / 50 \mathrm{~mL} \\
20 \mathrm{ppm}\end{array}$ & $\frac{t}{q}=0.825 t+0.253$ & 1.212 & 1.2039 & 0.999 & 0.17219 \\
\cline { 2 - 7 } & $\begin{array}{c}1 \mathrm{~g} / 50 \mathrm{~mL} \\
20 \mathrm{ppm}\end{array}$ & $\frac{t}{q}=1.030 t+0.300$ & 0.970 & 0.9654 & 0.999 & 0.31827 \\
\hline
\end{tabular}

\section{Diffusion model}

The film diffusion, intra particle diffusion or interaction mechanisms might explain the rate determining step in the present adsorption reaction. To identify the exact mechanism for determining the rate determining step, the following Weber and Morris model [36] equation has been used.

Weber diffusion model Eq. (9);

$\mathrm{q}_{\mathrm{t}}=K_{\text {diff }} \mathrm{t}^{0.5}+\mathrm{C}$

The data on metal uptake is now plotted against $\sqrt{t}_{\mathrm{t}}$ for optimum adsorbent dosage of $80 \mathrm{ppm}$ at 2 adsorbent dosages (Table 6). The data are shown segregated into 2 linear plots (A, B) of 2 different slopes. Plot A represents film diffusion while B represents intra-particle diffusion. The data are shown segregated into 2 linear curves with a distinct demarcation or break-up. This may be an indication that either film diffusion or intra-particle diffusion or together are controlling rate determining step. The plots A and B in Figure 11, however, show that film diffusion prevails predominantly.

where $\mathrm{K}_{\text {diff }}$ is the intra particle diffusion rate constant, $\mathrm{mg} / \mathrm{gm} \min ^{0.5}$

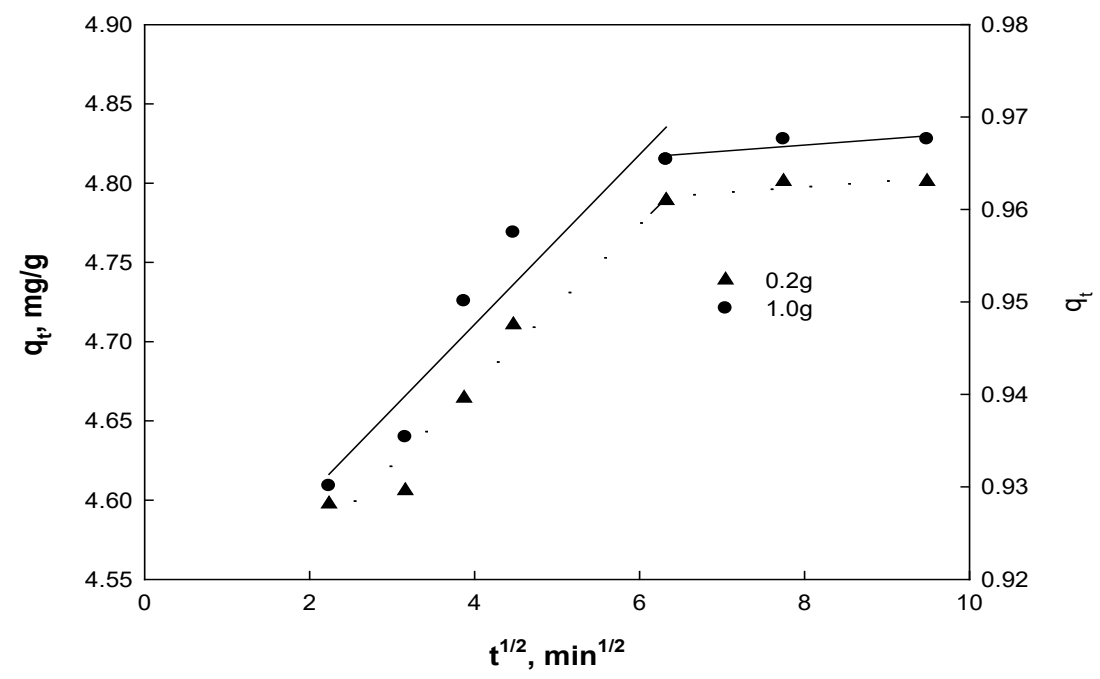

Figure 11 Intraparticle diffusion model for $\mathrm{Cu}(\mathrm{II})$. 
Table 6 Intraparticle diffusion for $\mathrm{Cu}(\mathrm{II})$.

\begin{tabular}{cccccc}
\hline S. No & Dosage, $\mathbf{g} / \mathbf{L}$ & Model equation & $\mathbf{K}_{\text {diff }}$ & Constant, $\mathbf{C}$ & $\mathbf{R}^{2}$ \\
\hline 1 & 0.2 & $q_{t}=0.0505 t^{0.5}+4.47$ & 0.0505 & 4.47 & 0.961 \\
2 & 0.2 & $q_{t}=0.0036 t^{0.5}+4.76$ & 0.0036 & 4.76 & 0.698 \\
3 & 1 & $q_{t}=0.0092 t^{0.5}+0.91$ & 0.0092 & 0.91 & 0.909 \\
4 & 1 & $q_{t}=0.0006 t^{0.5}+0.96$ & 0.0006 & 0.96 & 0.698 \\
\hline
\end{tabular}

\section{Adsorption thermodynamics}

The nature of heat interactions arise during adsorption between adsorbent and metal solution could be predicted from the thermodynamic data. These data can give us information whether the interactions are physical or chemical in nature. The study all through throw some light on the spontaneity of physical or chemical interactions [37,38]. In view of this, thermodynamic studies are carried out. The adsorbent adsorbate interactions are established to be pseudo second order [29]. The change in augmentation of adsorption with temperature has been explained on the basis of Entropy change $(\Delta S)$, Enthalpy change $(\Delta \mathrm{H})$ and Gibbs free energy change $(\Delta \mathrm{G})$.

The equilibrium constant values $\mathrm{K}_{\mathrm{D}}$, for $\mathrm{Cr}$ (VI) on MFLP was calculated at different temperatures by using the Eqs. (10) - (12). These values were used to evaluate the thermodynamic parameters using the following equations;

$K_{D}=C_{A E} / C_{E}$

$\Delta G=-R T \ln K_{D}$

$\ln k_{D}=\frac{\Delta S}{R}-\frac{\Delta H}{R T}$

where, $\Delta \mathrm{G}$ is the change in Gibbs free energy change $(\mathrm{KJ} / \mathrm{mol})$,

$\Delta \mathrm{H}$ is the change in enthalpy change $(\mathrm{KJ} / \mathrm{mol})$,

$\Delta \mathrm{S}$ is the change in entropy change $(\mathrm{KJ} / \mathrm{mol})$.

Sign of the $\Delta \mathrm{H}$ value indicates the endothermic/exothermic nature of adsorption reaction.

1) $\Delta \mathrm{H}(+\mathrm{ve})$ shows Endothermic reaction

2) $\Delta \mathrm{H}(-\mathrm{ve})$ indicates Exothermic reaction

The data on rate constant, $\mathrm{K}_{\mathrm{D}}$ calculated from pseudo-second order reaction equation (Eq. 12), were plotted against 1/T for all $\mathrm{C}_{\mathrm{o}}$ values and shown in Figure 12. The slopes and intercepts of these plots would give us all the thermodynamic data on $\Delta \mathrm{H}$ and $\Delta \mathrm{S}$ from which $\Delta \mathrm{G}$ can be calculated.

The data thus obtained for all the $\mathrm{C}_{\mathrm{o}}$ values at different temperatures the thermo dynamic data are compiled and shown in Table 7. reaction.

The $(-\mathrm{ve})$ values of $\Delta \mathrm{G}$ are presented in table below that clearly indicates the spontaneity of

The $(+\mathrm{ve})$ values for $\Delta \mathrm{H}$ indicate the adsorption reaction is endothermic nature.

The +ve values of $\Delta \mathrm{H}$ imply endothermic nature of adsorption and the values are + ve for $\mathrm{C}_{\mathrm{o}}$ from 40 ppm to $100 \mathrm{ppm}$. However, for $20 \mathrm{ppm}$ of $\mathrm{Cu}(\mathrm{II})$ solution the $\Delta \mathrm{H}$ value was negative $(-0.8 \mathrm{KJ} / \mathrm{mole})$ indicating that adsorption for this specific instance and is exothermic in nature. The values of $\Delta \mathrm{H}$ show how physical interactions are sufficiently strong for Copper (II) on MFLP adsorbent.

Gibbs free energy $(\Delta \mathbf{G})$

The $\Delta \mathrm{G}$ values of $\mathrm{Cu}(\mathrm{II})$ adsorption on MFLP under different temperatures were calculated using the equation;

$\Delta \mathrm{G}=-\mathrm{RT} \ln \mathrm{K}_{\mathrm{D}}$

Thermodynamic data for copper

The negative values of $\Delta \mathrm{G}$ are presented in Table 7. The - ve values of $\Delta \mathrm{G}$ imply spontaneous nature of adsorption. The $\Delta \mathrm{G}$ values varied from -5104 to $-8155 \mathrm{~J} / \mathrm{molK}$ as its temperature varied from 283 to $323 \mathrm{~K}$. 
Entropy $(\Delta \mathbf{S}): \Delta \mathrm{S}$ varied from 22 to $48 \mathrm{~J} / \mathrm{K}$ mol.

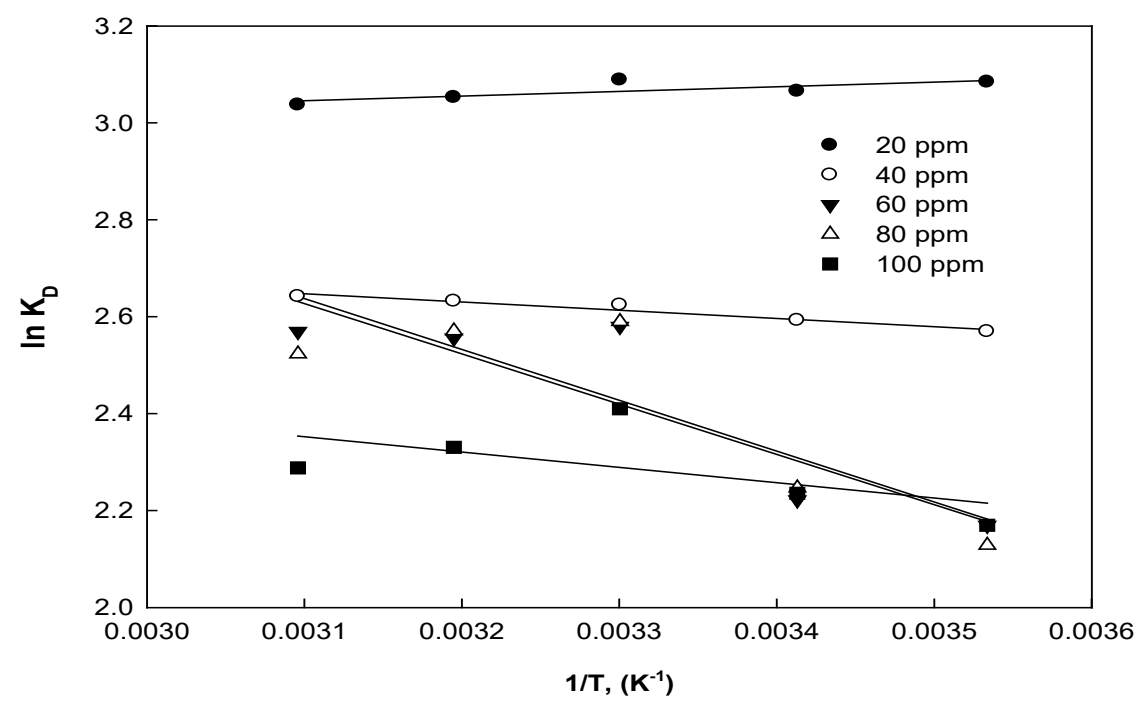

Figure 12 Thermodynamics plot for $\mathrm{Cu}(\mathrm{II})$.

Table 7 Thermodynamics data for copper and regression coefficients.

\begin{tabular}{|c|c|c|c|c|c|c|c|c|}
\hline $\begin{array}{c}\text { Initial } \\
\text { concentration }\end{array}$ & Equation & $\begin{array}{c}\Delta \mathbf{H}, \\
\text { J/mole }\end{array}$ & $\begin{array}{c}\Delta \mathrm{S}, \\
\mathrm{J} / \mathrm{mole} \\
\mathbf{K}\end{array}$ & & & $\Delta G, J / m o l$ & & \\
\hline ppm & & & & 283 & 293 & 303 & 313 & 323 \\
\hline 20 & $\begin{array}{c}\ln K_{D}=-95.94\left(\frac{1}{T}\right)+2.748 \\
R^{2}=0.595\end{array}$ & -797.64 & 22.846 & -7256.4 & -6045.7 & -5104.9 & -5007.8 & -5105.3 \\
\hline 40 & $\begin{array}{c}\ln \mathrm{K}_{\mathrm{D}}=169.73\left(\frac{1}{\mathrm{~T}}\right)+3.17 \\
\mathrm{R}^{2}=0.95\end{array}$ & 1411.14 & 26.355 & -7467.6 & -6316 & -5413.8 & -5473 & -5446.4 \\
\hline 60 & $\begin{array}{c}\ln K_{D}=1049.43\left(\frac{1}{T}\right)+5.89 \\
R^{2}=0.782\end{array}$ & 8724.96 & 48.969 & -7780.7 & -6610.7 & -6500.3 & -6524.3 & -6071.8 \\
\hline 80 & $\begin{array}{c}\ln K_{D}=1037.42\left(\frac{1}{T}\right)+5.84 \\
R^{2}=0.728\end{array}$ & 8625.11 & 48.553 & -7944.1 & -6849.4 & -6651.6 & -6689.3 & -6065.1 \\
\hline 100 & $\begin{array}{c}\ln K_{D}=316.95\left(\frac{1}{T}\right)+3.33 \\
R^{2}=0.359\end{array}$ & 2635.12 & 27.685 & -8155.8 & -7094.7 & -6901.4 & -6775.7 & -6144.7 \\
\hline
\end{tabular}

\section{Conclusions}

Experiments were carried out using Mallet Flower Leaf Powder. SEM and FTIR analysis showed the morphology and presence of active sites. The experimental data obtained was well represented by Langmuir $\left(\mathrm{RL}=0.161, \mathrm{qm}=5.96 \mathrm{mg} / \mathrm{g}, \mathrm{R}^{2}=0.9142\right)$, Freundlich $\left(\mathrm{n}=0.64, \mathrm{Kf}=0.79 \mathrm{~L} / \mathrm{g}, \mathrm{R}^{2}=0.9995\right)$ and Tempkin $\left(\mathrm{R}^{2}=0.9083, \mathrm{bT}=267.63\right)$ isotherms, indicating favorable biosorption. Apart from this, thermodynamic studies were also well accepted for the removal of copper. The results suggested favorable removal efficiency of copper from waste water using MFLP. The maximum adsorption capacity of MFLP was found to be $5.96 \mathrm{mg}$ of Copper/ gm of MFLP. 


\section{Acknowledgement}

The authors acknowledge the support of the management of MVGR College of Engineering (Autonomous) in conducting the research work leading to the award of $\mathrm{PhD}$ of the first author. The authors also wish to express gratitude to Prof. C. Baskara Sarma for his advice.

\section{References}

[1] AAS Al-Gheethi, I Norli, J Lalung, AM Azlan, ZAN Farehah and MOA Kadir. Biosorption of heavy metals and cephalexin from secondary effluents by tolerant bacteria. J. Clean Tech. Environ. Pol. 2014; 16, 137-48.

[2] AH Sulaymon, AA Mohammed and TJ Al-Musawi. Competitive biosorption of lead, cadmium, copper, and arsenic ions using algae. Int. J. Environ. Sci. Poll. Res. 2013; 20, 3011-23.

[3] A Witek-Krowiak. Application of beech sawdust for removal of heavy metals from water: Biosorption and desorption studies. Eur. J. Wood Wood Prod. 2013; 71, 227-36.

[4] A Hussain, J Maitra and KA Khan. Development of biochar and chitosan blend for heavy metals uptake from synthetic and industrial wastewater. J. App. Water Sci. 2017; 7, 4525-37.

[5] A Yazdani, M Sayadi and A Heidari. Green biosynthesis of palladium oxide nanoparticles using dictyota indica seaweed and its application for adsorption. J. Water Environ. Nanotech. 2018; 3, 337-47.

[6] B Krishna and P Venkateswarlu. Influence of Ficus religioso leaf powder on biosorption of cobalt. Indian J. Chem. Tech. 2011; 18, 381-90.

[7] A Celik and A Demirbas. Removal of heavy metal ions from aqueous solutions via adsorption onto modified lignin from pulping wastes. Energ. Sourc. 2005; 27, 67-77.

[8] DS Malik, CK Jain and AK Yadav. Removal of heavy metals from emerging cellulosic low-cost adsorbents: A review. J. App. Water Sci. 2017; 7, 2113-36.

[9] D Dutta, SK Roy, B Das and AK Talukdar. Removal of $\mathrm{Cu}(\mathrm{II})$ and $\mathrm{Pb}(\mathrm{II})$ from aqueous solutions using nanoporous materials. J. Phy. Chem. A 2018; 92, 976-83.

[10] E Bazrafshan, L Mohammadi, AA Moghaddam and A HosseinMahvi. Heavy metals removal from aqueous environments by electrocoagulation process - a systematic review. J. Environ. Health Sci. Eng. 2015; 13, 74-9.

[11] F Migahed, A Abdelrazak and G Fawzy. Batch and continuous removal of heavy metals from industrial effluents using microbial consortia. Int. J. Environ. Sci. Tech. 2017; 14, 1169-80.

[12] H Gao, R Tayebee, MF Abdizadeh, E Mansouri, M Latifnia and Z Pourmojahed. The efficient biogeneration of $\mathrm{Ag}$ and $\mathrm{NiO}$ nanoparticles from VPLE and a study of the anti-diabetic properties of the extract. RSC Adv. 2020; 10, 3005-12.

[13] H Rezaei. Biosorption of chromium by using Spirulina sp. Arabian J. Chem. 2016; 9, 846-53.

[14] IH Ali and HA Alrafai. Kinetic, isotherm and thermodynamic studies on biosorption of chromium (VI) by using activated carbon from leaves of Ficus nitida. Chem. Central J. 2016; 10, 36-42.

[15] KC Khulbe and T Matsuura. Removal of heavy metals and pollutants by membrane adsorption techniques. J. App. Water Sci. 2018; 8, 19-27.

[16] RM Kakhki, R Tayebee, M Mohammadpour and F Ahsani. Fast and highly efficient removal of anionic organic dyes with a new $\mathrm{Cu}$ modified nanoclinoptilolite. J. Inclusion Phenom. Macrocyclic Chem. 2018; 91, 133-9.

[17] M Athar, U Farooq, SZ Ali and M Salman. Insight into the binding of copper(II) by non-toxic biodegradable material (Oryzasativa): Effect of modification and interfering ions. J. Clean Tech. Environ. Pol. 2014; 16, 579-90.

[18] MH Sayadi, N Salmani, A Heidari and MR Rezaei. Bio-synthesis of palladium nanoparticle using Spirulina platensis alga extract and its application as adsorbent. Surface. Interfac. 2018; 10, 136-43.

[19] MH Sayadi, O Rashki and ES Shahri. Application of modified Spirulina platensis and Chlorella vulgaris powder on the adsorption of heavy metals from aqueous solutions. J. Environ. Chem. Eng. 2019; 7, 103-69.

[20] N Prakash, M Soundarrajan, SA Vendan, PN Sudha and NG Renganathan. Contemplating the feasibility of vermiculate blended chitosan for heavy metal removal from simulated industrial wastewater. J. App. Water Sci. 2017; 7, 4207-18.

[21] DV Padma and SVAR Sastry. Biosorption of hexavalent chromium using mallet flower leaves powder as adsorbent. TEST Eng. Manag. 2020; 83, 15714-29. 
[22] DV Padma and SVAR Sastry. Biosorption of divalent copper from aqueous solution using mallet flower leaves powder as adsorbent. Int. J. Environ. Waste Manag. 2021, https://doi.org/10.1504/IJEWM.2022.10036313.

[23] DV Padma and SVAR Sastry. Kinetic studies on simultaneous biosorption of divalent copper and hexavalent chromium using mallet flower leaf powder. J. Water Environ. Nanotech. 2020; 5, 20417.

[24] S Moulay and N Bensacia. Removal of heavy metals by homolytically functionalized poly (acrylic acid) with hydroquinone. Int. J. Ind. Chem. 2016; 7, 369-89.

[25] SVAR Sastry. Green synthesis and characterization of silver nano particles. J. Water Environ. Nanotech. 2020; 5, 81-91.

[26] SVAR Sastry and BS Rao. Studies on adsorption of $\mathrm{Cu}(\mathrm{II})$ using spent tea extract (STE) from industrial wastewater. J. Fut. Eng. Tech. 2016; 11, 31-5.

[27] SVAR Sastry and BS Rao. Determination of adsorption kinetics for removal of copper from wastewater using Spent Tea Extract (STE). J. Fut. Eng. Tech. 2017; 12, 27-32.

[28] SVAR Sastry, BS Rao and DV Padma. Studies on selective batch adsorption of Cu(II) and Cr(VI) from aqueous solution. TEST Eng. Manag. 2020; 83, 6794-7.

[29] H Shekari, MH Sayadi, MR Rezaei and A Allahresani. Synthesis of nickel ferrite/titanium oxide magnetic nanocomposite and its use to remove hexavalent chromium from aqueous solutions. Surface. Interfac. 2017; 8, 199-205.

[30] $\mathrm{S}$ Huang and $\mathrm{G}$ Lin. Biosorption of $\mathrm{Hg}(\mathrm{II})$ and $\mathrm{Cu}(\mathrm{II})$ by biomass of dried Sargassum fusiform in aquatic solution. J. Environ. Health Sci. Eng. 2015; 13, 21-9.

[31] S Choudhary, V Goyal and S Singh. Removal of Copper(II) and Chromium(VI) from aqueous solution using sorghum roots (S. bicolor): A kinetic and thermodynamic study. J. Clean Tech. Environ. Pol. 2014; 17, 1039-51.

[32] S Iram, R Shabbir, H Zafar and M Javaid. Biosorption and bioaccumulation of copper and lead by heavy metal resistant fungal isolates. Arabian J. Sci. Eng. 2015; 40, 1867-73.

[33] R Tayebee. Acid-thermal activated nanobentonite as an economic industrial adsorbent for malachite green from aqueous solutions: Optimization, isotherm, and thermodynamic studies. J. Water Environ. Nanotech. 2018; 3, 40-50.

[34] R Tayebeea and N Mollaniab. Bio-removal of carcinogenic Cr(VI) by whole cells and cell-free extracts of a new native and highly chromate-resistant Enterobacter sp. Desalin. Water Treat. 2018; 111, 258-66.

[35] VE Pakade, TD Ntuli and AE Ofomaja. Biosorption of hexavalent chromium from aqueous solutions by Macadamia nutshell powder. J. App. Water Sci. 2017; 7, 3015-30.

[36] WJ Weber, JC Morris and J Sanit. Kinetics of adsorption on carbon from solution. J. Sanitary Eng. Div. Am. Soc. Civ. Eng. 1963; 89, 31-8.

[37] XW Ang, VS Sethu, JM Andresen and MS Kumar. Copper(II) ion removal from aqueous solutions using biosorption technology: Thermodynamic and SEM-EDX studies. J. Clean Tech. Environ. Pol. 2013; 15, 401-7.

[38] Z Sfaksi, N Azzouz, AA Wahab. Removal of chromium from water by cork waste. Arabian J. Chem. 2014; 7, 37-42. 